\title{
Dietary iron deficiency and sports anaemia
}

\author{
BY LINDSAY M. WEIGHT, PETER JACOBS AND TIMOTHY D. NOAKES \\ Department of Haematology and Leukaemia Centre, and the UCT/MRC Bioenergetics of Exercise \\ Research Unit, University of Cape Town Medical School and Groote Schuur Hospital, Observatory, \\ Cape Town, South Africa
}

(Received 12 February 1991-Accepted 1 August 1991)

\begin{abstract}
In order to determine whether dietary inadequacies can explain the sub-optimal iron status widely documented in endurance-trained athletes, the food intake records of Fe-deficient and Fe-replete distance runners and non-exercising controls of both sexes were analysed. In all the male study groups the mean dietary Fe intake met the recommended dietary allowances (RDA; $>10 \mathrm{mg} / \mathrm{d}$ (US) Food and Nutrition Board, 1989). However, both female athletes and controls failed to meet the RDA with regard to $\mathrm{Fe}$ $(<15 \mathrm{mg} / \mathrm{d})$ and folate $(<200 \mu \mathrm{g} / \mathrm{d})$. There was no difference in the total $\mathrm{Fe}$ intakes of Fe-deficient and Fe-replete athletes and the controls of each sex. However, Fe-deficient male runners, but not female runners, consumed significantly less haem-Fe $(P=0.048)$ than their comparative groups. This suggests that the habitual consumption of Fe-poor diets is a factor in the aetiology of athletes' Fe deficiency.
\end{abstract}

Athletes: Sports anaemia: Iron status: Dietary iron: Recommended dietary allowances

Decreased serum ferritin (SF) levels $(<20 \mu \mathrm{g} / 1)$, suggestive of a precarious iron balance, are widely reported amongst endurance-trained athletes (Clement \& Asmundsen, 1982; Dickson et al. 1982; Magnusson et al. 1984a, b; Weight et al. 1988), particularly women (Colt \& Heyman, 1984; Lampe et al. 1986; Matter et al. 1987). The aetiology of this compromised Fe status is not clear, although lack of easily-absorbed dietary $\mathrm{Fe}$ is an important causative factor in the deficiency prevalent in both developed and Third World countries (Dallman et al. 1984). However, it would seem somewhat paradoxical that trained athletes, who presumably consume more kilojoules than a sedentary person, should become deficient in this mineral considering the correlation between the total energy and Fe content of the diet (Buskirk, 1977). However, it is also possible that some athletes do not practise dietary regimens that are nutritionally adequate, particularly vegetarians and those attempting to maintain low body-weights by energy restriction (Snyder et al. 1989). Nevertheless, such practices do not explain the apparently high incidence of Fe deficiency in distance runners.

The present study was, therefore, undertaken to document the relationship between dietary $\mathrm{Fe}$ intake and stores in male and female distance runners, and a non-exercising control group.

\section{METHODS AND MATERIALS \\ Subjects}

Sixteen male and twenty female distance runners who had been training $50-120 \mathrm{~km} /$ week for more than 2 years were stratified into two groups according to their haematological profile. Fe deficiency was designated when two of the three established clinical criteria 
(Cook et al. 1976), i.e. haemoglobin $(\mathrm{Hb} ; \mathrm{g} / 1)<140$ for males and $<120$ for females, SF $<20 \mu \mathrm{g} / 1$, and percentage transferrin saturation (\% sat) $<18 \%$, were met. The first group thus comprised four male and eight female Fe-deficient athletes, and the second, twelve male and twelve female athletes who were Fe replete $(\mathrm{Hb}>140 \mathrm{~g} / \mathrm{l}$ and $120 \mathrm{~g} / 1$ for males and females respectively, and SF $>20 \mu \mathrm{g} / 1)$. The control sample of eight males and eight females were recruited from among the University staff. None participated in any form of regular exercise, but were in good health and did not smoke nor take any prescription medication. Neither the distance runners nor controls were consuming supplementary $\mathrm{Fe}$, vitamins or minerals at the time of the study, nor had done so regularly in the previous 6 months. Any person who had voluntarily donated blood in the previous 12 months was excluded from the study.

Once the subjects had given their informed consent to participate in the study, a further blood sample was taken under the same conditions as in the screening study to confirm their haematological status. None of the female subjects were amenorrheic, and haematological and dietary data were collected at all phases of the menstrual cycle.

\section{Dietary record}

All participants were instructed to maintain their customary eating patterns and to record their intake for seven successive days. Standardized apparatus consisting of a balance, measuring cup and spoon was used to measure the mass of all solid and semi-solid foodstuffs, or volume of all liquids eaten during this $7 \mathrm{~d}$ period. Subjects were given detailed written and illustrated instructions on how to quantify specific food items and also to record only the amount of food actually consumed; that is, to subtract any plate waste. The recorded diets were analysed using the Floro Diet Programme (1987), which is based on the food composition tables compiled by the National Research Institute for Nutritional Diseases (Gouws \& Langenhoven, 1981), in order to obtain the daily average intake of all macro- and micronutrients. The proportion of haem- and non-haem-Fe in the diet was calculated according to the guidelines of Monson et al. (1978). Specifically, that $30 \%$ of the $\mathrm{Fe}$ in pork, liver and fish, and $50 \%$ in beef, lamb and chicken is in the form of haem-Fe. All other dietary Fe was assumed to be non-haem. None of the athletes were informed of their $\mathrm{Fe}$ status and to which study group they had been assigned before completing the dietary record.

\section{Haematological measurements}

The subjects reported to the laboratory for venepuncture at 08.00 hours after an overnight fast. They had not performed any running training in the preceeding $24 \mathrm{~h}$. A total of $20 \mathrm{ml}$ venous blood was drawn from an ante-cubital vein without stasis into appropriate vacutainers (Vacutest; Radem Laboratories, Sandton). A full blood count including Hb, packed cell volume, erythrocyte count, leucocyte count, mean cell volume, mean cell $\mathrm{Hb}$ and mean cell $\mathrm{Hb}$ concentration were performed on EDTA-blood using a Coulter Counter Model S II ${ }^{+}$(Rowan et al. 1979). Serum was stored frozen $\left(-20^{\circ}\right)$ for later determination of serum Fe (SI) and total Fe-binding capacity (TIBC) according to the method described by the International Committee for Standardization in Haematology $(1978 a, b)$, and SF levels by radioimmunoassay (Addison et al. 1972) using a commercial kit (Amersham International PIc, Amersham, UK). \% Sat was calculated from SI and TIBC levels.

\section{Statistical analysis}

An analysis of variance (ANOVA) was applied to the grouped data (Cary, 1985) to determine whether there were any significant differences between the groups. The data for the three male and three female groups were pooled into two groups according to sex, and 
Table 1. Demographic details of iron-deficient and Fe-replete endurance-trained athletes and their non-exercising controls $\dagger$

(Means and standard deviations)

\begin{tabular}{|c|c|c|c|c|c|c|c|c|c|c|c|c|}
\hline \multirow{3}{*}{$n \ldots$} & \multicolumn{6}{|c|}{ Males } & \multicolumn{6}{|c|}{ Females } \\
\hline & \multicolumn{2}{|c|}{$\begin{array}{c}\text { Fe-deficient } \\
4\end{array}$} & \multicolumn{2}{|c|}{$\begin{array}{l}\text { Fe-replete } \\
12\end{array}$} & \multicolumn{2}{|c|}{$\begin{array}{c}\text { Control } \\
8\end{array}$} & \multicolumn{2}{|c|}{$\begin{array}{c}\text { Fe-deficient } \\
8\end{array}$} & \multicolumn{2}{|c|}{$\begin{array}{c}\text { Fe-replete } \\
12\end{array}$} & \multicolumn{2}{|c|}{$\begin{array}{c}\text { Control } \\
8\end{array}$} \\
\hline & Mean & SD & Mean & SD & Mean & $\mathrm{SD}$ & Mean & SD & Mean & SD & Mean & SD \\
\hline Age (ycars) & $39 \cdot 8$ & $11 \cdot 1$ & $34 \cdot 0$ & 6.9 & $32 \cdot 8$ & $8 \cdot 1$ & 31.9 & $7 \cdot 3$ & $34 \cdot 4$ & $9 \cdot 1$ & $32 \cdot 8$ & $9 \cdot 6$ \\
\hline Mass (kg) & $64 \cdot 3$ & $6 \cdot 8$ & $69 \cdot 8$ & 60 & $73 \cdot 0$ & $7 \cdot 4$ & 53.5 & $3 \cdot 8$ & $56 \cdot 3$ & $4 \cdot 4$ & $51 \cdot 8$ & $5 \cdot 6$ \\
\hline Body mass index & $2 \mathrm{I} \cdot 4^{*}$ & $1 \cdot 5$ & $22 \cdot 5$ & $1 \cdot 8$ & $25 \cdot 0$ & $1 \cdot 7$ & $20 \cdot 0$ & $3 \cdot 2$ & $20 \cdot 5$ & 1.7 & $20 \cdot 2$ & $1 \cdot 3$ \\
\hline $\begin{array}{l}\text { Distance run } \\
\text { weekly }(\mathrm{km})\end{array}$ & 93.8 & $19 \cdot 2$ & $104 \cdot 0$ & $29 \cdot 0$ & & & $78 \cdot 8$ & $29 \cdot 0$ & $65 \cdot 9$ & $22 \cdot 0$ & & \\
\hline $\begin{array}{l}\text { No. of years } \\
\text { running }\end{array}$ & $8 \cdot 6$ & 57 & $8 \cdot 6$ & $6 \cdot 1$ & & & $4 \cdot 1$ & $2 \cdot 2$ & $5 \cdot 7$ & $2 \cdot 6$ & & \\
\hline $\begin{array}{l}\text { Marathon best } \\
\text { time (h:min) }\end{array}$ & $2: 57$ & $0: 25$ & $2: 39$ & $0: 17$ & & & $3: 14$ & $0: 20$ & $3: 36$ & $0: 38$ & & \\
\hline
\end{tabular}

Mean value for Fe-deficient male athletes was significantly different from that for male controls: ${ }^{*} P<0 \cdot 05$.

$\dagger$ For details of groups, see pp. 253-254.

scatter plots were constructed with the variables energy, protein, Fe, ascorbic acid and body mass, v. SF. A stepwise regression procedure using these same variables, with SF levels as the dependent variable, were then performed (Cary, 1985) in order to determine which indices should be used in a regression model. As this procedure did not reveal any significant trends, further analysis was not considered necessary. For all analysis $P<0.05$ was taken as the level of significance.

\section{RESULTS}

The demographic, haematological and dietary details are recorded in Tables 1, 2 and 3 respectively. The body mass index of the Fe-deficient male athletes was significantly lower $(P<0.05)$ than that of the other male groups. Although three criteria were used to assign the athletes to their study groups (SF concentration, $\mathrm{Hb}$ level and \% sat), the former appears to be the most critical factor given the significant differences in this variable between the male and female groups.

\section{Dietary and haematological status of the male athletes}

The mean SF level of the Fe-deficient male athletes $(14.8 \mu \mathrm{g} / 1)$ was significantly lower than that of their Fe-replete counterparts $(64.9 \mu \mathrm{g} / 1 ; P=0.0002)$ and the male controls $(73.2 \mu \mathrm{g} / 1 ; P=0.014)$. There was no significant difference in mean $\mathrm{Hb}$ concentration, nor any other nutritional variable including $\mathrm{Fe}$, between the groups.

The mean total energy ingested in both groups of athletes was lower than the recommended dietary allowances (RDA; (US) Food and Nutrition Board, 1989) for sedentary males $(11.34 \mathrm{MJ} / \mathrm{d})$, but all subjects consumed more than $1 \mathrm{~g}$ protein $/ \mathrm{kg}$ body mass per d (Table 3). Similarly, the mean Fe intakes of all male groups exceeded the RDA ((US) Food and Nutrition Board, 1989). However, the mean haem-Fe content of Fe- 
Table 2. Haematological characteristics of iron-deficient and Fe-replete endurance-trained atheletes and their non-exercising controls

(Mean values and standard deviations)

\begin{tabular}{|c|c|c|c|c|c|c|c|c|c|c|c|c|}
\hline \multirow{3}{*}{$n \ldots$} & \multicolumn{6}{|c|}{ Males } & \multicolumn{6}{|c|}{ Females } \\
\hline & \multicolumn{2}{|c|}{$\begin{array}{c}\text { Fe-deficient } \\
4\end{array}$} & \multicolumn{2}{|c|}{$\begin{array}{c}\text { Fe-replete } \\
12\end{array}$} & \multicolumn{2}{|c|}{$\begin{array}{c}\text { Control } \\
8\end{array}$} & \multicolumn{2}{|c|}{$\begin{array}{c}\text { Fe-deficient } \\
8\end{array}$} & \multicolumn{2}{|c|}{$\begin{array}{c}\text { Fe-replete } \\
\quad 12\end{array}$} & \multicolumn{2}{|c|}{$\begin{array}{c}\text { Control } \\
8\end{array}$} \\
\hline & Mean & $\mathrm{SD}$ & Mean & SD & Mean & SD & Mean & $\mathrm{SD}$ & Mean & $\mathrm{SD}$ & Mean & $\mathrm{SD}$ \\
\hline $\begin{array}{l}\text { Haemoglobin } \\
(\mathrm{g} / \mathrm{l})\end{array}$ & 132 & 14 & 146 & 7 & 154 & 8 & 123 & 15 & 132 & 15 & 130 & 20 \\
\hline Packed cell volume & $42 \cdot 0$ & $0 \cdot 1$ & $44 \cdot 0$ & $0 \cdot 1$ & $46 \cdot 0$ & $0 \cdot 0$ & $38 \cdot 0$ & 0.0 & $39 \cdot 0$ & $0 \cdot 0$ & $40 \cdot 0$ & 0.1 \\
\hline $\begin{array}{l}\text { Mean cell volume } \\
\text { (fl) }\end{array}$ & 91.9 & $8 \cdot 1$ & $92 \cdot 1$ & 5.9 & $88 \cdot 5$ & $2 \cdot 1$ & 91.9 & $7 \cdot 0$ & $93 \cdot 3$ & $3 \cdot 6$ & $89 \cdot 8$ & $4 \cdot 1$ \\
\hline $\begin{array}{l}\text { Percentage } \\
\text { transferritin } \\
\text { saturation }\end{array}$ & $24 \cdot 4$ & $8 \cdot 0$ & $31 \cdot 9$ & $11 \cdot 5$ & $39 \cdot 1$ & $7 \cdot 1$ & $24 \cdot 2$ & $12 \cdot 0$ & $32 \cdot 3$ & $11 \cdot 8$ & $30 \cdot 2$ & $5 \cdot 6$ \\
\hline $\begin{array}{l}\text { Serum ferritin } \\
(\mu \mathrm{g} / 1)\end{array}$ & $14 \cdot 8^{*}+\dagger$ & $4 \cdot 8$ & $64 \cdot 9$ & $31 \cdot 1$ & $73 \cdot 3$ & $50 \cdot 0$ & $11 \cdot 0^{*}$ & $4 \cdot 8$ & $63 \cdot 8 *$ & $31 \cdot 0$ & $34 \cdot 9$ & $29 \cdot 7$ \\
\hline
\end{tabular}

Mean values were significantly different from the corresponding control group: ${ }^{*} P<0 \cdot 05$.

Mean values for Fe-deficient male athletes were significantly different from those for Fe-replete male athletes: $\dagger+P<0.01$.

+ For details of groups, see pp. 253-254.

deficient male runners $(0.95 \mathrm{mg} / \mathrm{d})$ was significantly lower $(P=0.048)$ than that of the Fereplete male runners $(1.96 \mathrm{mg} / \mathrm{d}$ ) (Table 3 ). In all groups there was no correlation between the SF level and total energy, protein, Fe and ascorbic acid intakes, body mass or body mass index.

\section{Dietary and haematological status of the female athletes}

The mean SF level of the Fe-deficient female athletes $(11.0 \mu \mathrm{g} / \mathrm{l})$ was significantly lower than that of the Fe-replete female runners $(63.8 \mu \mathrm{g} / 1 ; P=0.0001)$ but not that of the control group $(34.9 \mu \mathrm{g} / \mathrm{l})$. The mean $\mathrm{Hb}$ level, total energy, protein and $\mathrm{Fe}$ intakes were not different between groups. In all groups there was no correlation between SF level and total energy, protein, ascorbic acid, body mass or body mass index.

As the mean energy intake of each group failed to meet the RDA $(9 \cdot 24 \mathrm{MJ} / \mathrm{d}$; (US) Food and Nutrition Board, 1989), and although the protein intake was adequate, the diets were sub-optimal with regard to Fe and folate (Table 3). Neither the mean total dietary Fe intake nor the haem proportion thereof was different between the three female groups.

\section{DISCUSSION}

An important finding in the present study is that endurance athletes of both sexes failed to meet the recommended energy intakes for sedentary persons (Table 3 ). This anomoly has been previously described in male and female endurance athletes (Weight et al. 1988; Snyder et al. 1989; Mulligan \& Butterfield, 1990) and the broader population (Nieman et al. 1989).

A second observation is that, although the deficient athletes of both sexes consumed no less $\mathrm{Fe}$ than did their replete counterparts, the mean haem-Fe proportion thereof was 


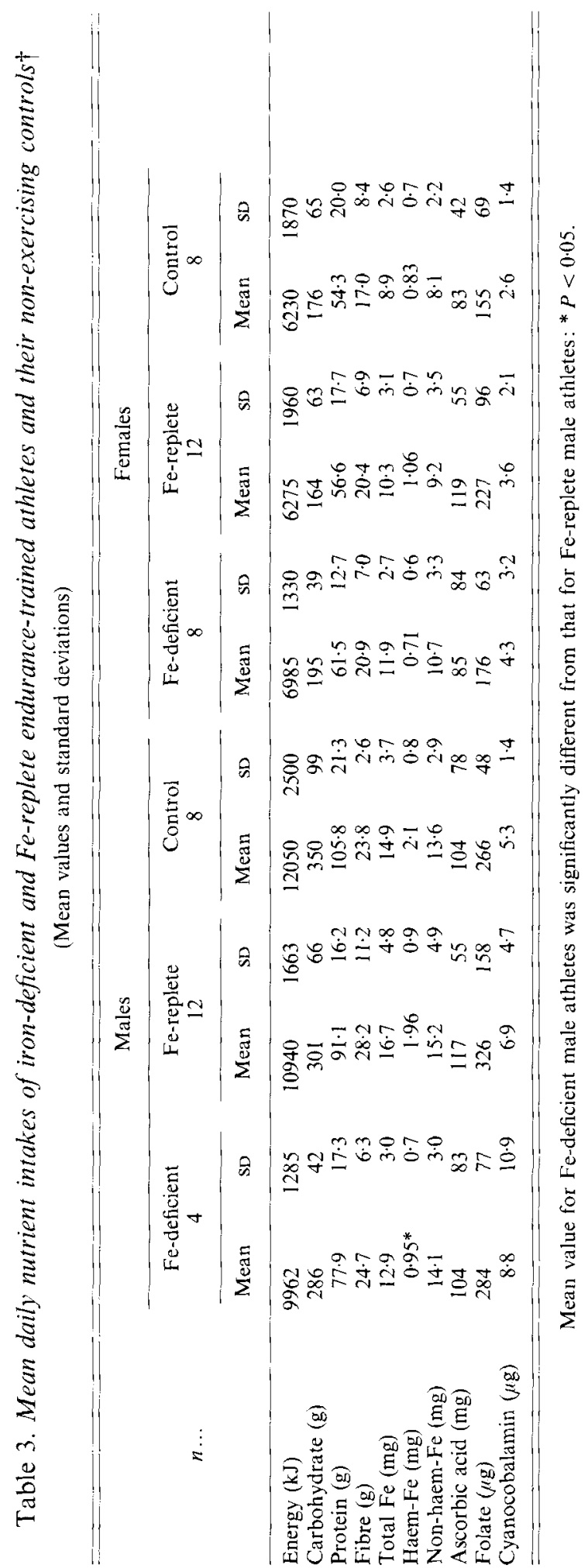


significantly lower in the hypoferritinaemic male runners $(P<0-05)$. No such differences were found between the female study groups. None of the runners or control subjects consumed strictly vegetarian diets, although some excluded red meat.

The absorption of non-haem-Fe is critically influenced by a number of other variables (Monson et al. 1978). In this study the amount of ascorbic acid, calcium, dietary fibre, tea (tannin) and coffee (caffeine) ingested daily were also noted but were found to bear no relationship to Fe status. In fact the only study to report a significant correlation between dietary Fe and SF levels was that of Deuster et al. (1986) who found a positive association in amenorrhoeic, but not eumenorrhoeic female athletes.

Despite the sub-optimal energy intakes of the male athletes, the individual nutrients content including Fe, but excluding folate, exceeded the RDA ((US) Food and Nutrition Board 1989) in all groups. This data is also comparable with our previous experience (Weight et al. 1988).

Conversely, most of the female athletes in the present study consumed nutritionally inadequate diets. Although uncompensated by the ingestion of vitamin and mineral supplements, these dietary practices were generally not reflected in a compromised haematological status. This observation is consistent with that of Miles et al. (1984) who comprehensively determined habitual $\mathrm{Fe}$ intakes in a representative sample of persons consuming a self-selected Western diet. Fe consumption was found to be consistent throughout a single year in both sexes, but bore no relationship to SF levels which also remained constant, although marginal in the females. Furthermore, the fact that there was no significant difference between the nutritional profiles of the athletic and control groups is in agreement with the observations of Risser et al. (1988).

Particular attention was paid to the protein consumption of these athletes, as Yoshimura (1970) and Shiraki et al. (1977) have contended that the early stages of training may produce a type of sports anaemia which has been related to an inadequate protein intake. The Japanese authors suggest that in the early stages of training a significant proportion of this macronutrient is used in muscle hypertrophy at the expense of $\mathrm{Hb}$ synthesis. However, it would seem unlikely that a fundamental physiological process such as oxygen transport should be compromised in order to facilitate an adaptational but not essential tissue hypertrophy. Moreover, the fact that this transient anaemia has not been confirmed by subsequent studies (Hegenauer et al. 1983), and the protein intakes of athletes, including those in the present study, have been shown to be adequate, further invalidates this suggestion regarding the aetiology of sports anaemia.

Although the present study is concerned only with the extent to which the habitual diet contributes to the Fe status of trained athletes, cognizance is given to the possibility of $\mathrm{Fe}$ loss. There is contradictory evidence of accelerated dermal, gastrointestinal or menstrual blood loss in rigorously exercising persons (Paulev, 1983), although the more recent studies negate a significant dermal loss. Gastrointestinal bleeding has been described in runners (Stewart et al. 1984; Fisher et al. 1986) but it is an infrequent occurrence, most usually associated with strenuous racing and often compounded by salicylate abuse.

Therefore, as in the larger population, inadequate Fe nutrition is an important factor in the $\mathrm{Fe}$ deficiency experienced by sports persons. Although Fe intake per se may be sufficient, habitual consumption of a vegetarian-type diet with a predominance of nonhaem-Fe-containing protein effectively compromises the nutritional Fe status of these athletes.

The work was supported by the South African Medical Research Council, the University of Cape Town Leukaemia Centre and the Staff Research Fund, the Gwendoline Moore Trust, the National Cancer Association, and the Michael Chanani and Kaliski bequests. 
The co-operation of the staff of the Haematology Laboratory, Groote Schuur Hospital is appreciated.

\section{REFERENCES}

Addison, G. M., Beamish, M. R., Hales, C. N., Hodgkins, M., Jacobs, A. \& Llewellin, P. (1972). An immunoradiometric assay for ferritin in the serum of normal subjects and patients with iron deficiency and iron overload. Journal of Clinical Pathology 25, 326 329.

Brune, M., Magnusson, B., Persson, H. \& Hallberg, L. (1984). Iron losses in sweat. American Journal of Clinical Nutrition 101, 127-128.

Buskirk, E. R. (1977). Diet and athletic performance. Postgraduate Medicine 61, 229-236.

Cary, N. C. (ed.). SAS Users Guide: Statistics. Version 5. Los Angeles: BMDP Statistical Services Inc.

Clement, D. B. \& Asmundsen, R. C. (1982). Nutritional intake and hematological parameters in endurance runners. Physician and Sports Medicine 10, 37-43.

Colt, E. \& Heyman, B. (1984). Low ferritin levels in runners. Journal of Sports Medicine 24, 13-17.

Cook, J. D., Skikne, B. S., Lynch, S. R. \& Reusser, M. E. (1976). Estimates of iron deficiency in the US population. Blood $68,726-731$.

Dallman, P. R., Yip, R. \& Johnson, C. (1984). Prevalence and causes of anaemia in the United States 1976-1980. American Journal of Clinical Nutrition 39, 436-445.

Deuster, P. A., Kyle, S. B., Moser, P. B., Vigersky, R. A., Singh, A. \& Schoomaker, E. B. (1986). Nutritional intakes and status of highly-trained amenorrheic and eumenorrheic women runners. Fertility and Sterility $\mathbf{4 6}$, $636-643$

Dickson, D. N., Wilkinson, R. L. \& Noakes, T. D. (1982). Effects of ultra-marathon training and racing on hematologic parameters and serum ferritin levels in well-trained athletes. International Journal of Sports Medicine 3, 111-117.

Fisher, R. L., McMahon, L. F., Ryan, M. J., Larson, D. \& Brand, M. (1986). Gastrointestinal bleeding in competitive runners. Digestive Diseases and Sciences 31, 1226-1228.

Floro Diet Programme (1987). Floro Diet Data Programme, version SA030. Vlaardingen, Netherlands: Unilever Research Laboratories.

Food and Nutrition Board (1989). Recommended Dietary Allowances, 10th revised ed. Washington: National Academy of Sciences.

Gouws, E. \& Langenhoven, M. L. (1981). NRIND Food Composition Tables. Parow: Medical Research Council of South Africa.

Hegenauer, J., Strauss, L., Saltman, P., Dann, D., White, J. \& Green, R. (1983). Transitory haematological effects of moderate exercise are not influenced by iron supplementation. European Journal of Applied Physiology $\mathbf{5 2}$, $57-61$.

International Committee for Standardization in Haematology. (1978a). Recommendations for the measurement of total and unsaturated iron-binding capacity. British Journal of Haematology 38, 281-290.

International Committee for Standardization in Haematology $(1978 \mathrm{~b})$. Recommendations for the measurement of serum iron in human blood. British Journal of Haematology 38, 291-294.

Lampe, J. W, Slavin, J. L. \& Apple, F. S. (1986). Poor iron status of women training for a marathon. International Journal of Sports Medicine 7, 111 114.

Magnusson, B., Hallberg, L., Rossander, L. \& Swolin, B. (1984a). Iron metabolism and 'sports anaemia'. I. A study of several iron parameters in elite athletes with differences in iron status. Acta Medica Scandinavica 216, 149156

Magnusson, B., Hallberg, L., Rossander, L. \& Swolin, B. (1984b). Iron metabolism and 'sports anaemia'. II. A haematologic comparison of elite runners and control subjects. Acta Medica Scandinavica 216, $157-164$.

Matter, M., Stitfall, T., Graves, J., Myburgh, K., Adams, B., Jacobs, P. \& Noakes, T. D. (1987). The effect of iron and folate therapy on maximal exercise performance in female marathon runners with iron and folate deficiency. Clinical Science 72, 415422.

Miles, C. W., Collins, J. S., Holbrook, J. T., Patterson, K. Y. \& Bodwell, C. E. (1984). Iron intake and status of men and women on self-selected diets. American Journal of Clinical Nutrition 40, 1393 1396.

Monson, E. R., Hallberg, L., Layrisse, M., Hegsted, D. M., Cook, J. D., Mertz, W. \& Finch, C. A. (1978). Estimation of available dietary iron. American Journal of Clinical Nutrition 31, 134-141.

Mulligan, K.\& Butterfield, G. E. (1990). Discrepencies between energy intake and expenditure in physically active women. British Journal of Nutrition 64, 23-36.

Nieman, D. C., Butler, J. V., Pollett, L. M., Dietrich, S. J. \& Lutz, R. D. (1989). Nutrient intake of marathon runners. Journal of the American Dietetic Association 89, 1273-1278

Patulev. P. E., Jordal, R. \& Petersen, N. S. (1983). Dermal excretion of iron in intensely training athletes. Clinica Chimica Acta 127, 19-27.

Risser, W. L., Lee, E. J., Poindexter, H. B. W., West, M. S., Pivarnik, J. M., Risser, J. M. H. \& Hickson, J. F. (1988). Iron deficiency in female athletes; its prevalence and impact on sports performance. Medicine and Science in Sports and Exercise 20, 116-121. 
Rowan, R. M.. Fraser, C., Gray, J. H. \& McDonald, G. A. (1979). The Coulter Counter Model S Plus - the shape of things to come. Clinical and Laboratorv Haematology 1, 29-40.

Shiraki, K., Yamada, T.\& Yoshimura, H. (1977). Relation of protein nutrition to the reduction of red blood cells induced during physical training. Japanese Journal of Physiology 27, 413-421.

Stewart, J. G., Ahlquist, D. McGill, D. B., Ilstrup, D. M. \& Schwartz, S. (1984). Gastrointestinal blood loss and anaemia in runners. Annals of Internal Medicine 100, 843-845.

Snyder, A. C., Dvorak, L. L. \& Rocpke, J. B. (1989). Influence of dictary iron source on measures of iron status among female runners. Medicine and Science in Sport and Exercise 21, 7-10.

Weight, L. M., Noakes, T. D., Labadarios, D., Graves, J., Jacobs, P. \& Berman, P. (1988). Vitamin and mineral status of trained athletes including the effects of supplementation. American Journal of Clinical Nitrition 47 , 186191

Yoshimura, H. (1970). Anaemia during physical training (sports anaemia). Nutrition Reviews 28, 251 -253. 